\title{
Local Consumption
}

\author{
Tim Kerja PSP2M
}

\begin{abstract}
The research was conducted in Waimangit Village of Buru Regency with the objectives to analyze community food security planning, make projections for diversification of local food consumption and food security in Waimangit Village. The approach used is qualitative with the basic method of descriptive analysis. The results showed that, Local food consumption is still low with the level of diversification of food consumption is also still low, factors that affect the level of diversification of food consumption is, expertise in processing, number of household members and social interaction, There is no shift of rice consumption pattern to local food, local food consumption condition only occurs at certain age segmentation, Food security level generally belong to food vulnerable where household is long term plant based farmer.
\end{abstract}

Keywords: Consumption, Diversification, Local Communities, Waimangit, Buru

\section{INTRODUCTION}

Development of food security in Buru Regency to continue revitalizing agriculture in order to realize food independence, increasing competitiveness of agricultural products, increase in farmer's income, and environmental and natural resource sustainability, but in certain parts, food security is difficult to realize when the issue of public consumption is reversed with the planning that has been carried out by the government[1].

Food diversification is intended not to replace rice entirely, but changing and improving people's consumption patterns so that more diverse types of food with better nutritional quality. Understanding and understanding wrong food diversification[2], predicted because of the assumption that rice is a staple food in Indonesia, despite the fact that people in several regions in Indonesia consume corn, sago, cassava and sweet potatoes as staple food. Because food problems are always fixed on rice[3], so that government policy programs compiled and implemented tend to be entrenched only around rice[4].

In a study conducted by Elizabeth regarding the strategy of achieving food diversification and independence, suggested food pattern shifting community of non rice into the rice as it did in Madura, Moluccas and other eastern Indonesia Area. Even the original sago in Maluku as a staple food, have switched $90-100 \%$ to rice, equal North sumatra and West Sumatra[5]. In the meantime, Hardono in his studies of the diversified development strategy of delivering local food phenomena that occur in a few locations such as Nusa tenggara, Papua, Maluku and Sulawesi is the change in the pattern of community food from local food such as dominant maize, tubers, and sago palms turned toward the national food patterns (rice), then turned towards international wheat-based food patterns[6].

Understanding the consumption patterns of the community Waimangit, can be described that the consumption of local food communities woke up with a variety of natural conditions as well as local wisdom they possessed. Consumption patterns that can be used has not been fully implemented due to changes in the flow of communication and the opening of transportation on a geographic community buru[7], so has the influence on the mindset and consumption patterns that are the result of correlation and interaction with people from outside the village.

It should be understood more than it is, that the structure of society that have a strong relationship with the environment, make the potential to create a diversified consumption of the greater, this is supported by the availability of local plants as well as land in the Village of Waimangit.

The purpose of this study is to get an overview about the conditions of food security as well as planning food security made by the community for the sustainability of life in the Village Waimangit[8]. The specification of the research developed to look at the technique of diversification of consumption in relation to the availability of local food in the Village Waimangit.

This form of writing is an overview of the descriptive results of the field research, using the approach phenomenology, the results of writing are arranged with the pattern as follows; introduction to descriptive concepts and theories used in the study. Next, the research method used, characterize how the tool is used to get sources of information and data with accurate

\section{LITERATURE REVIEW}

\subsection{Diversification of Consumption}

Diversification is an activity or action to make things more diverse or not fixed in just one type. Diversification of food consumption is an activity to consume food (especially staple food) through various types of food so it is not dependent on one food type. In Indonesia, which is a part of the population consuming rice[9], rice is one of the important things to be considered for its availability. Even people who once consumed sago and corn, many have turned to Rice because the reason for ease of access get it either in terms of the age of the plant or the process of processing[10]. Diversification of food consumption through diverse sources of carbohydrates can reduce consumption of national rice. This is considered effective for reducing rice imports and strengthening food security. In Indonesia there are many types of tubers and cereal sources of carbohydrate substitute rice, such as cassava, sweet potato, sago, corn, Porang, Gembili, Garut, Ganyong, and many more whose nutritional value is not inferior, even has Excess than rice[11]. From the habit we consume local food other than rice, there are some benefits that we can achieve, that is; (1) Reduce the import of rice dependence. If a once eat rice consume 0.5 ounces of rice then each day replace a portion of the meal with a nonrice feeding, then in a year one can reduce about $17.8 \mathrm{~kg}$ of rice consumption per year. It is only 
one, if we do it in congregation, it will be very positive impact for the independence of rice from Indonesia. (2) Local wisdom refers to Community policy regarding its local potential. That Indonesia is able to produce local rice for the needs of its residents can make a policy on its potential. (3) Complete nutritional needs[12]. The nutritional needs of the body cannot be fulfilled only from one food but rather need diversity of food resources. Suppose rice does not contain vitamin A as it is in corn, or it does not contain antioxidants such as those found in purple yam

\subsection{Food Security of Local Communities}

Formally, there are at least five international organisations that provide a definition of food security. Such definitions are considered complementary to one another, including; (1) First World Food Conference 1974, United Nations, 1975 Food security is the worldwide food availability that is sufficient at all times to preserve the sustainability of food consumption, and balance production and price fluctuations[13]. (2) FAO (Food and Agricultural Organization), 1992 Food security is a situation where everyone at all times has a sufficient amount of food that is safe and nutritious for a healthy and active life[14]. (3) The World Bank, 1996 Food security is the access by everyone at all times over sufficient food for a healthy and active life[15]. (4) OXFAM, 2001 Food security is the condition when everyone at all times has access and control over the adequate amount of food and good quality for healthy and active living. There are two meanings listed here, which are availability in the sense of quality and quantity, and access to the right to food through the purchase, Exchange, or claim[16]. (5) FIVIMS (Food Insecurity and Vulnerability Information and Mapping Systems), 2005 Food security is a condition when everyone at all times physically, socially, and economically, has access to adequate, safe, and nutritious food, to Fulfillment of consumption needs (dietary needs) and food preference (food preferences) for an active and healthy life[17].

Finally, from several formulas on the definition of food security according to various food agencies above, it can be concluded that food security is a condition that guarantees the availability of food production, the distribution of food, and the People acquire and choose healthy food for their lives[18]. Food is everything that comes from sources of biological and water, whether processed or not processed, that is intended as food or beverage for human consumers, including food additives and other materials used in the preparation process, processing and manufacture of food or beverage. Processed foods are food or beverage process results in a way or method with or without additives[19]. The term food or food in the word Mandarin is written two parts that one means human or human and the other means good or good. It means that food is supposed to be good, quality and safe when consumed by humans. Food terms are more used as technical terms, such as food technology, not food technology, food production instead of food production, food additives are not food additives. Food term used for the food that has been processed.

\section{Method}

The study was conducted in Waimangit Village, Buru Regency, Maluku Province. Location selection was done deliberately with the consideration that Waimangit Village had a large area of productive land for significant local food. The research was conducted from January to May 2019. The research conducted with qualitative methods and descriptive analysis approach.

The main data sources in qualitative research are words and actions, the rest are additional data such as photo documentation, recordings and other similar written works[20]. With regard to data, the types of data can be divided into words and actions, written data sources, photos and statistics[21]. In this research, The data collection techniques that I use are in-depth interviews with the Waimangit Village community and also Stakeholders and direct observation of the research object[22][23][24]. By utilizing community habits that like to gather at night, then the interview is carried out starting at 19.00-23.00.

For data analysis, the author did it when the data collection took place, after completion of data collection in a certain period. By analyzing data while collecting it, the author can find out directly the lack of data that must be collected and the method that must be done next in order to obtain comprehensive results.

By presenting data, researchers can work faster and more precisely in coding and decision making based on the focus of the research. The presentation of data is inseparable from the analysis of qualitative research data. The presentation of data part of the analysis as well as data reduction is also part of the analysis[25]. The presentation of data in qualitative research in general is matrices, graphs, charts, and narrative texts. Drawing conclusions/verification is the end of qualitative research data analysis. Drawing conclusions is done by means of data reflection.

\section{RESULt}

In general, the people who inhabit the area of Waimangit Village are characteristics of the people who have experienced changes in the development process in Buru Regency[26]. The increase in population, the increase in the level of education and the development of the economic sector make Waimangit Village one of the most developed regions. In its development we can see the condition of the population of Waimangit Village through the following table:

From the table data submitted, there was an increase in the number of significant increases in 2016 which was around 95 people or approximately 10 percent of the total population. Most of the people of Waimangit Village work as farmers, with the availability of natural resources in the form of farming land, the work in the agricultural sector becomes the primary orientation for their livelihoods. In further developments, people who have a rural culture should have a close consumption pattern for 
local products such as sago, sweet potatoes, cassava and banana, but in its development found a shift in consumption patterns that are different from the previous time, so that there is a need for a re-mapping of consumption patterns. The following table presents a plan for consumption patterns that occur in communities in Waimangit Village.

Table data shows that in the structure of society there is a differentiation of consumption patterns which are divided into three, that is, on the structure of civil servants and the police generally consume rice as the primary ingredient, then the entrepreneurial and entrepreneurial structure of rice is still the primary food ingredient, as well as farmers who still make rice as primary consumption material.

So in general it can be said, the consumption planning pattern that occurs in the community in Waimangit Village is still focused on rice as a staple food, even though there were also a small number of entrepreneurs and farmers who consumed sweet potatoes, sago and cassava as primary consumption ingredients, but only as a distraction to restrain household economic expenditure.

The next segment takes the form of a community consumption pattern that is divided into the age sector which is one form of stratification within the Waimangit Village community.

In the table the percentage of consumption patterns are divided by age, It is seen that rice is still the dominant consumption material for people aged 1-35 years, while for ages 36-56 years, rice is no longer the dominant staple for consumption due to an increase in the percentage of sago and sweet potato consumption.

\section{Discussion}

Consumption diversification is an alternative for the community to obtain various sources of carbohydrates from other types of plants besides rice. Efforts made by the community through a planning model by empowering the ability of economic resources are seen as a characteristic of rural communities in fulfilling their needs[27], People who work as administrative and entrepreneurial employees with a certain scale and type of business result in economic resources becoming a separate force in the primary consumption pattern[28]. That means, that the strength of income from work becomes a knot for meeting needs, in the end, consumption choices lead to something that is instant like rice, though some of them also choose tubers or bananas but more because of their economic ability.

On the other side, the ability of households in the Waimangit village community to empower sources of labor and leisure in the agricultural sector, become a support in fulfilling consumption. This condition is considered as an alternative economic structure as can be explained that the strength of the number of family members as a supporting power gets economic resources in fulfilling consumption[29]. The planning model in this sector found patterns of rice consumption as primary consumption, while the tubes and bananas are still an alternative consumption.

Some of the factors that cause the community in the segmentation still make rice as primary consumption material, that is because of cultural changes that occur due to acculturation that cause changes in mindset and patterns of action are affected, so that dependence on rice is still very dominant [30]. Sago is a good source of consumption in balancing people's consumption patterns. The habit of consuming sago at ritual and ceremonial events in Waimangit Village, indicates the segmentation of society in this sector is beginning to change, from the previous one that had become the primary turned into secondary[31], the reason people no longer consume indisputable sago is ritual and ceremonial phenomena, because the food served is made from sago and is a favorite consumption.

In the third planning model, the Waimangit community, which is a farmer profession, makes rice and sago a source of primary consumption. There are several causative factors, namely habits or traditions that already existed before, Waimangit community with age above 40 years has experienced a cultural situation by undergoing consumption of rice only at certain times, namely on Fridays every week[32]. This condition is the basis of the habit for them to consume sago and sweet potatoes. Availability of resources such as agricultural land and labor in the family, cause the community in the segmentation to be able to survive a balanced consumption pattern, between rice and local consumption materials such as sago, tubers and bananas.

With this plan, most of the people of Waimangit make work a source of consumption and a source of economic income, where the results obtained for sale are to increase household income[33]. Cultural problems are important when people in this segment are still able to maintain consumption patterns[34]. Habits that are maintained can keep them in simple life that does not have high economic dependency.

In general, there are two kinds of diversification, namely horizontal diversification; diversifying food consumption by increasing the variety of food commodities and increasing the production of these types of commodities, vertical diversification; diversifying processing of food commodities, especially non rice so that it has added value in terms of economy, nutrition and social[35].

In agricultural development, diversification is generally associated with a shift or transfer of export commodities to the direction of exploiting new commodities which are seen as a way out in facing market demand. Agricultural diversification is an election and adoption of several additional market-oriented commodity types, to be produced through modern agricultural cultivation, both at national and regional levels[36]. Agricultural diversification is a complex and broad business to improve the agricultural economy through efforts to diversify commodities in the production subsystem, consumption and distribution both at the regional and national farm level towards achieving the structural transformation of the agricultural sector towards resilient agriculture[37]. 
Community efforts to diversify agriculture must also be supported by the availability of adequate natural resources, for people in Waimangit Village these sources are not something that is difficult to obtain given their geographical location and socio-cultural conditions that are in rural areas with very good land carrying capacity[38]. The problem of diversification in Waimangit Village is not entrenched in the availability or carrying capacity of the region, but more as a result of community knowledge and socio-cultural conditions that cause a shift in mindset and behavior towards consumption patterns.

Waimangit Village Community is a structure of the community with a connection and dependence on nature, with diversification that has been done of course with two approaches, namely horizontal and vertical diversification. The following are presented data on horizontal diversification carried out by the Waimangit village community:

On horizontal diversification tables, rice is still the basic ingredient in consumption for the people of Waimangit Village. Community efforts to increase the variety of food commodities are still limited by making sago, yams and bananas only as an alternative source. In certain parts, the dominance of rice against other types of basic ingredients began to decrease, certainly with the use of other basic ingredients as an alternative food source, it has even become a staple food source. In the last column, the status of rice and sago is the same in quality but different in quality.

In previous studies, most of the inhabitants of the Insana Barat District are represented by the village of Usapinonot in consuming rice, corn and tubers. As per the habits that exist during the corn harvest season, people will consume more corn[39]. This is different from what happened in Waimangit Village, that there is no connection between the harvest season and the pattern of consumption of the community, but instead a ceremonial celebration in the village that causes people to consume local food such as sago and sweet potatoes and bananas.

The cause of rice becomes dominant towards local food sources, like the research conducted by Yuni Hamid that there is a tendency for the level of energy consumption of grain foods, namely rice as the staple food in the village is higher than in the city while on the contrary energy consumption from animal food, beans and vegetables / fruit is higher in the city than in the village[40]. Of course, this condition is in line with the findings in Waimangit Village, which considers rice as a representation in fulfilling energy consumption. In the research conducted by Wardayanie, most plants such as cassava, sweet potato can be consumed immediately after boiling, frying or burning[41]. For product diversification, traditional processing has been available, for example, processing cassava into chips, tiwul, gatol and so on. While for sweet potatoes, is not different in the process of cultivation of tubers, which can be made into sauce according to the sweet potato varieties and followed by different qualities.

This condition as explained earlier, that the lack of knowledge and utilization of technology has caused the participation of the Waimangit villagers in the utilization of natural resources is still very simple, diversification is not done for marketing production, but by a group of people trying to develop but not as a main source of income.

\section{CONCLUSION}

From the discussion that has been described, there are several things that can be stated as the conclusion that the dependence on rice which is still high in the community and the reduced level of consumption participation has resulted in stagnant food consumption diversification efforts. Many factors influence these conditions and are related to others. In essence, social, cultural, economic factors, knowledge are the causes that influence the diversification of food consumption and the causes are identical to the causes that affect the food consumption of local people. In addition, the availability of natural resources for local food sources is not followed by patterns of development and consumption patterns, in the act of making local food as a source of consumption, limited knowledge and information regarding local food causes the community to care less about the existence of local food sources in Waimangit. The shift in mindset that has an impact on patterns of behavior has led to traditions that previously supported local food consumption shifting to primary consumption, which gave birth to community dependence on rice becoming very dominant. Such conditions cause food vulnerability due to community dependence on rice.

\section{REFERENCES}

[1] A. Wael et al., "“ Bupolo' Motion Reading," Int. J. Sci. Technol. Res., vol. 8, no. 9, pp. 2154-2158, 2019.

[2] M. C. B. Umanailo, ILMU SOSIAL BUDAYA DASAR, 1st ed. Namlea: FAM PUBLISHING, 2015.

[3] M. C. B. Umanailo, “Kalesang Dorp in Context De Bouw van Village," 2019, pp. 1-7.

[4] M. C. B. Umanailo, "Integration of Community Empowerment Models [Pengintegrasian Model Pemberdayaan Masyarakat]," Proceeding Community Dev., vol. 2, p. 268, Mar. 2019.

[5] M. C. B. Umanailo, "Discourse on the Consumerist Community Consumption," J. Soc. Sci. Res., vol. 5, no. 54, pp. 1181-1186, Apr. 2019.

[6] M. C. B. Umanailo, "Studi pada Masyarakat Desa Waimangit Kabupaten Buru," SOCA, vol. 12, no. 12, pp. 63-74, 2018.

[7] M. C. B. Umanailo, M. Nawawi, and S. Pulhehe, "KONSUMSI MENUJU KONSTRUKSI MASYARAKAT KONSUMTIF," Simulacra, vol. 1, no. 2, pp. 203-211, 2018. 
[8] M. C. B. Umanailo, "Strategi Bertahan Hidup Petani Padi Gogo di Pulau Buru," J. Ekon. Pertan. dan Agribisnis, vol. 3, no. 1, pp. 50-58, Jan. 2019.

[9] M. C. B. Umanailo, " BUPOLO " Movement. 2019.

[10] M. C. B. Umanailo, "Postmodernisme dalam pandangan jean francois lyotard," 2018.

[11] S. Rachman, H. Hamiru, M. C. B. Umanailo, Y. Yulismayanti, and H. Harziko, "Semiotic Analysis of Indigenous Fashion in The Island of Buru," Int. J. Sci. Technol. Res., vol. 8, no. 8, pp. 1515-1519, 2019.

[12] M. C. B. Umanailo et al., "Cybercrime Case as Impact Development of Communication Technology That Troubling Society," Int. J. Sci. Technol. Res., vol. 8, no. 9, pp. 1224-1228, 2019.

[13] H. Hamiru et al., “Eucalyptus Oil Workers," Int. J. Sci. Technol. Res., vol. 8, no. 9, pp. 1817-1820, 2019.

[14] W. Malmia et al., "Problem-Based Learning as an Effort to Improve Student Learning Outcomes," Int. J. Sci. Technol. Res., vol. 8, no. 9, pp. 1140-1143, 2019.

[15] M. C. B. Umanailo, M. Yulisvestra, K. K. Oki, W. Mulyasari, and R. Ridwan, "The Thought of Emile Durkheim in the Contestation of Development in Indonesia," Int. J. Sci. Technol. Res., vol. 8, no. 8, pp. 1881-1885, 2019.

[16] R. Bugis et al., "Workers in the Namlea Market," Int. J. Sci. Technol. Res., vol. 8, no. 9, pp. 2044-2047, 2019.

[17] M. C. B. Umanailo, MASYARAKAT BURU DALAM PERSPEKTIF KONTEMPORER (Kajian Kritis Perubahan Sosial di Kabupaten Buru), vol. 1. Namlea, 2017.

[18] M. C. B. Umanailo et al., "Dominance of Economic Capital in Political," in Community Development, Decentralization $\mathcal{E}$ Local Autonomy Politic \& Democracy, Fisip Universitas Brawijaya, 2018, pp. 1-120.

[19] M. C. B. Umanailo, "'recycling' consumerism to construction of modern society," no. 1904, 1964.

[20] M. C. B. Umanailo, Marginalisasi Buruh Tani Akibat Alih Fungsi Lahan. 2016.

[21] M. C. B. Umanailo and T. Yatno, Kajian dan Analisis Sosiologi Dalam Bentuk Kumpulan Essay, Makalah dan Opini. 2015.

[22] M. C. B. Umanailo, R. Umanailo, R. Bugis, and A. T. Bon, "Empowerment Community in Buru Regency," in Proceedings of the International Conference on Industrial Engineering and Operations Management, 2019, pp. 2070-2075.

[23] M. N. Marshall, "Sampling for qualitative research," Fam. Pract., 1996.

[24] M. C. B. Umanailo, I. Hamid, M. Nawawi, S. Pulhehe, S. Yusuf, and A. T. Bon, "Utilization of Qualitative Methods in Research Universities," in Proceedings of the International Conference on Industrial Engineering and Operations Management, 2019, pp. 2076-2081.

[25] L. Rumkel, B. Sam, and M. C. B. Umanailo, “Village Head Partnership, Village Consultative Body and Customary Institution in Village Development," Int. J. Sci. Technol. Res., vol. 8, no. 8, pp. 1058-1063, 2019.

[26] S. S. F. Assagaf et al., "Construction of the Village as a Development Shaft in the Island Buru," Int. J. Sci. Technol. Res., vol. 8, no. 9, pp. 2139-2143, 2019.

[27] A. Hasan Afandi and M. C. B. Umanailo, "Watudakon Citizens 'Social Conflict on Joker Toll Road Development in 2017 in Kesamben District, Jombang Regency," J. Soc. Sci. Res., vol. Special Is, no. 5, pp. 656-661, 2018.

[28] M. C. B. Umanailo, "Keterbatasan penggunaan teknologi informasi pada pelayanan dan pembelajaran di universitas iqra buru," 2016.

[29] M. C. B. Umanailo, Sosiologi Hukum, 1st ed. Namlea: FAM PUBLISHING, 2016.

[30] B. S. Amanto, M. C. B. Umanailo, R. S. Wulandari, T. Taufik, and S. Susiati, "Local Consumption Diversification," Int. J. Sci. Technol. Res., vol. 8, no. 8, pp. 1865-1869, 2019.

[31] M. C. B. Umanailo, "EKSISTENSI WARANGGANA DALAM RITUAL TAYUB.”

[32] S. Yusuf, M. C. B. Umanailo, R. N. Putri, D. Qhuril, M. Ely, and D. Darma, "Village Institution Relations in the Utilization of Village Funds in Namlea District," Int. J. Sci. Technol. Res., vol. 8, no. 8, pp. 1837-1842, 2019.

[33] M. C. B. Umanailo, N. Handayani, A. Masniati, S. H. Makatita, and S. Lisaholit, "The Urbanization and Diversification of Farmland Namlea Village," Int. J. Sci. Technol. Res., vol. 8, no. 8, pp. 1049-1053, 2019.

[34] M. C. B. Umanailo, "Overview of Phenomenological Research," 2019, pp. 1-6.

[35] M. C. B. Umanailo, “Teknik praktis grounded theory dalam penelitian kualitatif," 2018, no. April, p. 127.

[36] L. J. Buton et al., "The Effect of Nasa Liquid Organic Fertilizer Concentration and Planting Distance to Growth and Production of Beans," Int. J. Sci. Technol. Res., vol. 8, no. 9, pp. 2144-2147, 2019.

[37] M. C. B. Umanailo, MASYARAKAT BURU DALAM PERSPEKTIF KONTEMPORER, vol. 53, no. 9. 2015.

[38] A. L. Wabula, M. Musyawir, A. Irmawati, B. Rebel, D. M. Darajat, and M. C. B. Umanailo, "Maghrib Movement," Int. J. Sci. Technol. Res., vol. 8, no. 9, pp. 2134-2138, 2019.

[39] M. C. B. Umanailo et al., “Comprehension To Village,” 2018, pp. 1-2.

[40] B. Sam et al., "Female Feminism in the Customary Island of Buru," Int. J. Sci. Technol. Res., vol. 8, no. 8, pp. 18771880, 2019.

[41] M. C. B. Umanailo, “Desa Sebagai Poros Pembangunan Daerah,” 2015. 